\title{
PENGARUH PEMBERIAN TERAPI TOMAT (Lycopersicum grandi folium) TERHADAP PENURUNAN TEKANAN DARAH PADA LANSIA DENGAN HIPERTENSI DI PSTW "PUSPAKARMA" MATARAM
}

\author{
Hastuti Handayani $^{(1)}$, Kusmiyati ${ }^{(2)}$ dan Ni Made Sumatywati ${ }^{(3)}$ \\ (1) dan (3) Program Studi Ilmu Keperawatan Sekolah Tinggi Kesehatan (STIKES) Mataram \\ (2) Program Studi Pendidikan Biologi Fakultas Keguruan dan Ilmu Pendidikan Unram
}

\begin{abstract}
ABSTRAK
Proses menua dalam perjalanan hidup manusia terjadi terus menerus dan berkelanjutan secara alami. Lansia mengalami berbagai perubahan, baik secara fisik maupun mental. Perubahan yang terjadi pada lansia salah satunya pada sistem kardiovaskuler yaitu terjadi penurunan elastisitas pembuluh darah, sehingga meningkatkan resistensi pembuluh darah perifer yang mengakibatkan tekanan darah tinggi (hipertensi). Tomat mengandung betakarotin dan vitamin E sebagai anti oksidan yang dapat mencegah aglutinasi darah, sehingga dapat menurunkan tekanan darah. Tujuan penelitian ini adalah untuk mengetahui pengaruh terapi tomat terhadap penurunan tekanan darah pada lansia hipertensi di PSTW "Puspakarma" Mataram. Penelitian ini menggunakan desain Quasy eksperimen pre post desain. Berdasarkan tehnik total sampling didapatkan 22 respoden. Sampel dibagi menjadi kelompok kontrol dan kelompok eksperimen masing-masing terdiri dari 11 orang. Kelompok eksperimen diberi perlakuan terapi tomat dan kelompok kontrol tidak diberikan perlakuan. Penelitian ini dilakukan selama 21 hari pada lansia dengan hipertensi ringan, sedang, dan berat, Data di analisa dengan statistik uji t dengan taraf kesalahan 5\%. Pada kelompok perlakuan sebelum diberikan perlakuan terapi tomat sebagian besar responden berada pada hipertensi sedang sebanyak 8 responden $(72$, $73 \%$ ), pada kelompok kontrol sebagian besar berada pada hipertensi sedang 5 responden $(45,46 \%)$. Kelompok perlakuan setelah diberikan terapi tomat, sebagian besar responden berada pada hipertensi ringan 6 reponden (54,54\%), pada kelompok kontrol sebagian besar berada hipertensi sedang sebanyak 7 responden $(63,64 \%)$. Hasil uji t didapatkan nilai t hitung $=4,46>\mathrm{t}$ tabel $(0,05)=2,086$, sehingga dapat disimpulkan bahwa pemberian terapi tomat berpengaruh signifikan terhadap penurunan tekanan darah pada lansia dengan hipertensi di PSTW "Puspakarma" Mataram.
\end{abstract}

Kata-kata kunci: Lansia, Penurunan tekanan darah, Terapi Tomat

\begin{abstract}
Aging process on the way human life are continuous ongoing in nature. Elderly underwent several changes, both physically and mentally.changes that happened in the elderly one of them on the cardivasculer system that is a decrease in the elasticity of blood vessels so that increasing peripheral vascular resistance which results in high blood pressure (hypertension). Betakarotin and tomatoes contain vitamin $\mathrm{E}$ as and antioxidant that can prevent the agglutination of blood so that it can lower blood pressure. The purpose of this study was to determine the therapeutic effect of tomatoes to the decrease of blood pressure in elderly with hypertension in PSTW "Puspakarma" Mataram. This study uses experimental design Quasy pre post design. Sampling techniquebased on a total of 22 respondents obtained. The first group is 11 people who were subjected to treatment of tomato and other groups are not given treatment. Research was done for 21 days subject to the classification of blood pressure havemild hypertension, moderate, severe, statistical analysis used was the test with significance level of $5 \%$. In the treated group before therapy treatment of tomato given the majority of respondents are in hypertension are as many as 8 respondents $(72.73 \%)$, in the
\end{abstract}


control group are mostly located in hypertension is five respondents (45.46\%). Treatment groups after the treatment given in the form of tomato therapy most of the respondents are in mild hypertension 6 respondents $(54.54 \%)$, largely in the kontrol group were hypertension was as much as 7 respondents (63.64\%). Test results of the test statistic $t$ found the value $t$ count $=4.46>\mathrm{t}$ table $(0,05)=2.086$. The conclusion of this study is a complementary therapy (therapy tomato) effect on blood pressure reduction in elderly hypertensive in PSTW "Puspakarma" Mataram.

\section{Key words: Elderly, decrease in blood pressure, Tomato Therapy}

\section{PENDAHULUAN}

$\mathrm{H}$ ipertensi (tekanan darah tinggi) merupakan penyebab kematian nomor tiga didunia setelah stroke dan tuberculosis, yakni mencapai sekitar 6,7 $\%$.. Jumlah penderita hipertensi di seluruh dunia terus meningkat, di Indonesia, banyaknya penderita hipertensi diperkirakan 15 juta, tetapi hanya 4\% yang merupakan hipertensi terkontrol. Prevalensi 6-15\% pada orang dewasa, $50 \%$ diantaranya tidak menyadari sebagai penderita hipertensi, sehingga mereka cenderung untuk menjadi hipertensi berat, karena tidak menghindari dan tidak mengetahui faktor resikonya. Saat ini penyakit degeneratif dan kardiovaskuler sudah merupakan salah satu masalah kesehatan masyarakat di Indonesia. Prevalensi hipertensi di Indonesia menurut Survey Kesehatan Rumah Tangga / SKRT (2004), pada orang yang berusia 25 tahun ke atas menunjukkan bahwa $27 \%$ laki-laki dan 29\% wanita menderita hipertensi (Akhmad, 2010).

Panti Sosial Tresna Werdha (PSTW) adalah wadah atau institusi yang memberikan pelayanan dan perawatan jasmani, rohani dan sosial serta perlindungan untuk memenuhi kebutuhan lansia agar dapat menikmati taraf hidup secara wajar (Depsos RI, 2002). Jumlah lansia pada tahun 2008-2010 sebanyak 86 orang, dengan umur lansia antara 60-86 tahun, pada tahun 2008 jumlah lansia yang menderita hipertensi sebanyak 20 orang, tahun 2009 jumlah lansia yang menderita hipertensi sebanyak 22 orang, sedangkan pada tahun 2010 lansia yang menderita hipertensi tidak mengalami peningkatan yaitu sebanyak 22 orang.

Menurut Basha (2009), hipertensi adalah suatu keadaan dimana seseorang mengalami peningkatan tekanan darah di atas normal, yang mengakibatkan angka kesakitan atau morbiditas dan angka kematian atau mortalitas. Sustrani dkk (2005) menyebutkan, hipertensi atau penyakit darah tinggi adalah gangguan pada pembuluh darah yang mengakibatkan suplai oksigen dan nutrisi yang dibawa oleh darah terhambat sampai kejaringan tubuh yang membutuhkannya. Hipertensi sering kali disebut sebagai pembunuh gelap (silent killer), karena termasuk yang mematikan tanpa disertai dengan gejala-gejalanya lebih dahulu sebagai peringatan bagi korbannya.

Penyebab penyakit hipertensi di antaranya arterosklerosis (penebalan dinding arteri yang menyebabkan hilangnya elastisitas pembuluh darah), keturunan, bertambahnya jumlah darah yang dipompa ke jantung, penyakit ginjal, kelenjar adrenal, dan sistem saraf simpatis, obesitas, tekanan psikologis, stres, dan ketegangan (Marzuky 2009).

Hipertensi dapat di cegah agar tidak menyebabkan komplikasi lebih lanjut dengan diperlukan penanganan yang tepat dan efisien. Menurut Marlia (2009) secara umum penanganan hipertensi dapat dilakukan secara farmakologis dan non-farmakologis. Penanganan secara farmakologis terdiri atas pemberian obat yang bersifat diuretik, simpatetik, betabloker, dan vasodilator 
dengan memperhatikan tempat, mekanisme kerja dan tingkat kepatuhan. Penanganan non-farmakologis meliputi penurunan berat badan, olah raga secara teratur, diet rendah lemak dan garam, dan terapi komplementer. Penanganan secara non farmakologis sangat diminati oleh masyarakat karena sangat mudah untuk dipraktekkan dan tidak mengeluarkan biaya yang terlalu banyak. Selain itu, penanganan non farmakologis juga tidak memiliki efek samping yang berbahaya, sehingga masyarakat lebih menyukai penanganan secara non farmakologis dari pada secara farmakologis.

Salah satu dari penanganan non farmakologis dalam menyembuhkan penyakit hipertensi yaitu terapi komplementer. Terapi komplementer bersifat terapi pengobatan alamiah diantaranya adalah dengan terapi herbal, terapi nutrisi, relaksasi progresif, meditasi, terapi tawa, akupuntur, akupresur, aromaterapi, terapi bach flower remedy, dan refleksologi. Terapi herbal banyak digunakan oleh masyarakat dalam menangani penyakit hipertensi, dikarenakan memiliki efek samping yang sedikit. Jenis yang digunakan dalam terapi herbal yaitu tomat

\section{BAHAN DAN METODE}

Alat dan bahan yang digunakan dalam penelitian ini adalah tomat, blender, timbangan, dandang, sphygmomanometer (tensimeter) dan stetoskop. Subjek pada penelitian ini adalah semua lansia yang mengalami hipertensi, sedangkan populasinya adalah semua lansia yang mengalami hipertensi di PSTW "Puspakarma" Mataram. Sampel dalam penelitian ini adalah lansia yang mengalami hipertensi ringan, sedang dan berat yang ada di PSTW "Puspakarma" Mataram, sebanyak 22 orang dengan tehnik pengambilan sampel total sampling.

Penelitian ini menggunakan Quasy

Sebelum memberikan perlakuan terapi tomat, terlebih dahulu dipilih tomat yang berbentuk bulat besar, dan tidak rusak (Gambar 1), setelah itu tomat di timbang,
(Lyocopercison lycopersicum), seledri atau celery (Apium graveolens), bawang putih atau garlic (Allium sativum), bawang merah atau onion (Allium cepa), semangka (Citrullus vulgaris) ( Sustrani, dkk 2005).

Tomat merupakan salah satu jenis terapi herbal untuk menangani penyakit hipertensi. Menurut Azwar Agoes (2007), ekstrak tomat mempunyai kandungan seperti lykopen yang efektif untuk menurunkan kolesterol, betakarotin dan vitamin $\mathrm{E}$ sebagai anti oksidan yang dapat mencegah aglutinasi darah, sehingga dapat menurunkan tekanan darah. Kadar lykopen yang terkandung dalam tomat merupakan salah satu alasan tomat digunakan sebagai alternatif untuk mengurangi gejala hipertensi. tingginya kejadian hipertensi pada lansia merupakan dasar untuk menerapkan pemberian terapi tomat secara rutin, dimana di PSTW "Puspakarma" Mataram belum pernah dilakukan pemberian terapi tomat terhadap penderita hipertensi oleh karena itu peneliti tertarik untuk melakukan penelitian mengenai manfaat tomat khususnya dalam penurunan tekanan darah.

eksperiment.pre-postest desain' Rancangan ini berusaha untuk mengungkapkan sebab akibat dengan kelompok kontrol disamping kelompok eksperimen Dalam penelitian ini, 22 responden tersebut kemudian dibagi menjadi dua kelompok yakni kelompok kontrol dan kelompok eksperimen, pada kedua kelompok diukur tekanan darahnya (sebagai data pretest) dan sama-sama diberikan terapi farmakologi captopril $25 \mathrm{mg}$. Pada kelompok kontrol hanya diberikan terapi farmokologi tanpa diberi tomat, sedangkan kelompok eksperimen diberikan terapi farmakologi yang diikuti dengan terapi tomat. Setelah diberikan terapi tomat ke dua kelompok diukur tekanan darahnya (sebagai data postest). kemudian dicuci sampai bersih, kemudian tomat di kukus dengan waktu 3 menit, setelah di kukus tomat dihaluskan dengan menggunakan blender kemudian di tuang ke 
dalam gelas saji dengan ukuran $120 \mathrm{cc}$, diberikan sebanyak 2 kali sehari pada jam 08.00 dan 12.00 WITA selama 21 hari.

Data tekanan darah dikumpulkan dengan menggunakan (tensimeter) dan stethoscope, dalam posisi duduk. Pengukuran tekanan darah dilakukan sebelum dan sesudah perlakuan. Data dianalisis menggunakan uji-t dengan taraf kesalahan $5 \%$.

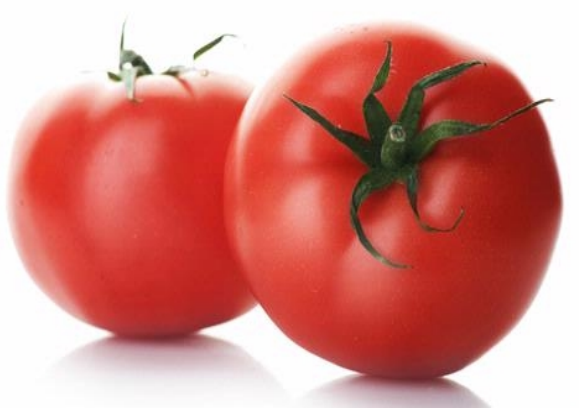

Gambar 1. Tomat

\section{HASIL DAN PEMBAHASAN}

Hasil pengukuran tekanan darah lansia pada kelompok eksperimen sebelum diberikan terapi tomat dan kelompok kontrol, terangkum pada Tabel 1. Data tersebut digunakan sebagai data pretest.

Tabel 1. Status Tekanan Darah Kelompok Eksperimen dan Kelompok Kontrol

\begin{tabular}{|c|c|c|c|c|c|c|}
\hline \multicolumn{4}{|c|}{ Kelompok eksperimen } & \multicolumn{3}{|c|}{ Kelompok kontrol } \\
\hline No & Status tekanan darah & Jumlah & $\%$ & Status tekanan darah & Jumlah & $\%$ \\
\hline 1 & Ringan & 2 & 18,18 & Ringan & 4 & 36,36 \\
\hline 2 & Sedang & 8 & 72,73 & Sedang & 5 & 45,46 \\
\hline 3 & Berat & 1 & 9,09 & Berat & 2 & 18,18 \\
\hline & Total & 11 & 100 & & 11 & 100 \\
\hline
\end{tabular}

Tabel 1 menunjukkan bahwa sebagian besar responden pada kedua kelompok mengalami hipertensi sedang. Berdasar hasil observasi, hipertensi sedang tersebut dengan sistol antara $150-170 \mathrm{mmHg}$ dan diastole antara
90-100 mmHg. Pemilahan status hipertensi tersebut sesuai dengan kategori tekanan darah menurut Sutomo (2009), sebagai berikut: 


\begin{tabular}{|l|c|c|}
\hline \multicolumn{1}{|c|}{ Kategori } & Sistolik(mmHg) & Diastolik(mmHg) \\
\hline Normal & $120-129$ & $80-84$ \\
\hline Hipertensi ringan & $140-159$ & $85-89$ \\
\hline Hipertensi sedang & $160-179$ & $90-99$ \\
\hline Hipertensi berat & $180-209$ & $90-99$ \\
\hline Hipertensi sangat berat & 210 & 110 \\
\hline
\end{tabular}

Lansia yang menjadi responden dalam penelitian ini berumur 65-85 tahun. Kisaran umur tersebut berisiko terkena hipertensi. Menurut Hadi (2004) patogenesis hipertensi pada usia lanjut sedikit berbeda dengan yang terjadi pada orang dewasa, faktor yang berperan pada usia lanjut adalah a) Penurunan kadar renin karena menurunnya jumlah nefron akibat proses menua (Aging Proses); b) Peningkatan sensitivitas terhadap asupan natrium. Makin lanjut usia makin sensitif terhadap peningkatan atau penurunan kadar natrium; c). penurunan elastisitas pembuluh darah perifer akibat proses menua akan meningkatkan resistensi pembuluh darah perifer yang pada akhirnya akan mengakibatkan hipertensi sistolik saja. Potter \& Perry (2005) menambahkan, tekanan darah cenderung meningkat seiring bertambahnya usia, sedangkan menurut Smeltzer \& Bare (2001), sejalan dengan bertambahnya usia struktur jantung dan pembuluh darah mengalami perubahan yang berkontribusi terhadap peningkatan tekanan darah. Perubahan ini meliputi aterosklerosis, hilangnya jaringan ikat, dan penurunan relaksasi otot polos pembuluh darah yang berakibat pada berkurangnya kemampuan aorta dan arteri dalam mengakomodasi darah yang dipompa oleh jantung, mengakibatkan penurunan curah jantung dan peningkatan tahanan perifer. Hal ini juga terdapat pada $14 \%$ penderita di atas usia 60 tahun, terutama pada pria. Setelah menopause perempuan mengalami peningkatan tekanan darah lebih tinggi dari pada laki-laki. Hasil temuan Ekowati \& Sulistyowati (2009), bahwa faktor risiko hipertensi pada kelompok usia $\geq 70$ tahun lebih tinggi 11,53 kali dibandingkan kelompok usia 25-34 tahun yaitu 1,56 kali. Hal ini menunjukkan risiko hipertensi meningkat bermakna sejalan bertambahnya usia.

Pada saat penelitian ditemukan lansia yang berumur 70 tahun ke atas memiliki aktivitas yang lebih sedikit dibandingkan yang masih berumur 65 tahun. Mereka lebih banyak istirahat tidur, dan duduk santai, sedangkan mereka yang masih berumur 60an tahun diakui masih kuat melakukan pekerjaan seperti,membuat kerupuk dari nasi, memasak, dll. Menurut Martuti (2009), kurangnya olahraga atau beraktivitas cenderung meningkatkan tekanan darah. Tjokronegoro (2001) menambahkan tekanan darah yang lebih rendah dijumpai pada individu yang fisiknya lebih sehat, latihan fisik secara teratur sangat dianjurkan untuk mencegah hipertensi dan penyakit jantung, sebab lemak tidak akan tertimbun di dalam tubuh sehingga aliran darah akan lancar.

Hasil pengukuran tekanan darah lansia pada kelompok eksperimen setelah diberikan terapi tomat dan kelompok kontrol terangkum pada Tabel 2. Data tersebut digunakan sebagai data postest. Tabel 2 menunjukkan bahwa setelah diberikan terapi tomat sebanyak 11 responden mengalami hipertensi ringan dan 5 responden $(45,46 \%)$ memiliki tekanan darah normal. Pada kelompok kontrol yang tidak diberikan terapi tomat, sebagian besar responden yaitu 7 responden $(63,64 \%)$ tetap mengalami hipertensi sedang dan 1 responden $(9,09 \%)$ berada pada tekanan darah normal. Dengan demikian terjadi penurunan tekanan darah setelah diberikan terapi tomat, dari tingkat hipertensi ringan menjadi normal dan hipertensi sedang menjadi ringan. Hasil uji statistik dengan uji t didapatkan nilai t hitung 
$=4,46>\mathrm{t}$ tabel $(0,05)=2,086$, yang berarti bahwa pemberian terapi tomat berpengaruh signifikan terhadap penurunan tekanan darah pada lansia dengan hipertensi di PSTW
"Puspakarma" Mataram. Hal ini dapat dipahami karena dalam tomat terdapat antioksidan yang dapat menurunkan tekanan darah.

Tabel 2 Status Tekanan Darah Kelompok Eksperimen dan Kelompok Kontrol

\begin{tabular}{|c|c|c|c|c|c|c|}
\hline \multicolumn{4}{|c|}{ Kelompok eksperimen } & \multicolumn{3}{|c|}{ Kelompok kontrol } \\
\hline No & Status tekanan darah & Jumlah & $\%$ & Status tekanan darah & Jumlah & $\%$ \\
\hline 1 & Normal & 5 & 45,46 & Normal & 1 & 9,09 \\
\hline 2 & Ringan & 6 & 54,54 & Ringan & 3 & 27,27 \\
\hline 3 & Sedang & 0 & 0 & Sedang & 7 & 63,64 \\
\hline 4 & Berat & 0 & 0 & Berat & 0 & 0 \\
\hline & Total & 11 & 100 & & 11 & 100 \\
\hline
\end{tabular}

Menurut Azwar Agoes (2007), kandungan tomat yang dapat menurunkan tekanan darah antara lain: a) Betakarotin dan vitamin $\mathrm{E}$ sebagai anti oksidan yang dapat mencegah aglutinasi darah, sehingga dapat menurunkan tekanan darah; b).Lykopen pada tomat adalah zat yang efektif untuk menurunkan kolesterol; c).Vitamin B6 dan folat, dibutuhkan tubuh untuk mengubah homosistein menjadi senyawa yang lebih tidak berbahaya. Kadar homosistein yang tinggi dapat membahayakan dinding pembuluh darah dan dihubungkan dengan meningkatkan resiko serangan jantung dan stroke; d).Kalium dapat menurunkan tekanan darah dan mengurangi resiko penyakit jantung.

Hasil observasi menunjukkan bahwa sebagian besar responden laki-laki adalah perokok, kondisi ini mempermudah terjadinya hipertensi, seperti pendapat Bangun (2003) yang menyatakan bahwa,

\section{KESIMPULAN}

Pemberian terapi tomat berpengaruh signifikan terhadap penurunan tekanan darah pada lansia dengan hipertensi di PSTW" merokok dapat mempermudah terjadinya penyakit pembuluh darah, serta dapat meningkatkan denyut jantung dan tekanan darah sementara. Hal ini disebabkan oleh pengaruh nikotin dalam peredaran darah, sehingga dapat disimpulkan bahwa rokok mempunyai hubungan besar dengan kejadian hipertensi. Penelitian lain menyatakan rokok juga dapat meningkatkan agregasi platelet dan menyebabkan spasme arteri coronary, nikotin berperan dalam meningkatkan tekanan dan suplai darah ke jantung (Leuckenotte dalam Suastana, 2010). Penurunan tekanan darah setelah pemberian terapi tomat menunjukkan bahwa dalam tomat terdapat zat yang dapat melawan kandungan yang merugikan pada rokok. Seperti pendapat Azwar Agoes (2007), bahwa di dalam tomat mengandung asam kumarat dan asam khlorogenik yang melawan nitrosamine, yang merupakan karsinogen utama yang terdapat dalam rokok

Puspakarma" Mataram, yang ditunjukkan dengan hasil uji $\mathrm{t}$ didapatkan nilai $\mathrm{t}$ hitung $=$ $4,46>\mathrm{t}$ tabel $(0,05)=2,086$ 


\section{DAFTAR PUSTAKA}

Akhmad 2010. Penyakit Degeneratif. Jakarta: PT Gramedia Pustaka Utama.

Azwar Agoes, 2007. Kandungan tomat.

Diakses pada 5 oktober 2011

http://www.google.co.id/kandungan+ tomat+untuk+menurunkan+tekanan + darah.

Bangun. 2003. Terapi Jus \& Ramuan

Tradisional Untuk Hipertensi.

Jakarta: Agromedia Pustaka

Basha, 2009. Keperawatan: Konsep, Proses, dan Praktik. Volume 2. Alih Bahasa: Renata Komalasari, dkk. Jakarta : EGC.

Depsos RI. 2002. Standarisasi Pelayanan Kesejahteraan Sosial Panti Sosial Tresna Werdha (PSTW). Jakarta.

Ekowati, R. \& Sulistyowati, T. 2009.

Prevalensi Hipertensi dan

Determinan di Indonesia.

(diakses

http://www.repositoryusu.abst ract.ac.id)diperoleh November 2011.

Hadi, M. 2004. Buku Ajar Geriatrik:

Penatalaksanaan Hipertensi Pada

Usia Lanjut. Jakarta: Balai Penerbit

FK UNDIP

Marlia, 2009. Cegah Hipertensi.diakses pada tanggal 21/april/2009 dari http://www.unpad.ac.id/archive/16 $\underline{429}$.

Martuti. 2009. Merawat dan Menyembuhkan Hipertensi (Penyakit Tekanan Darah Tinggi). Bandung: Kreasi Wacana

Marzuky 2009. penyebab penyakit hipertensi. diakses pada tanggal 3 januari 2010. http://www.e-psikologi.com

Perry \& Potter. 2005. Buku Ajar Fundamental Keperawatan: Konsep, Proses, dan Praktik. Volume 2. Alih Bahasa: Renata Komalasari, dkk. Jakarta : EGC.
Smeltzer, S dan Bare, B. 2001. Buku ajar Keperawatan Medikal Bedah Brunner \& Suddart. Jakarta: EGC.

Sustrany, L., dkk. 2005. Hipertensi. Jakarta: Gramedia Pustaka Utama .

Suastana. 2010. Efektifitas Masase Punggung Terhadap Penurunan Tekanan Darah Kelayan Hipertensi di Panti Sosial Tresna Werdha Puspakarma Mataram

Sutomo Budi. 2009. Menu Sehat Penakluk Hipertensi. Jakarta: Demedia

Tjokronegoro, A. 2001. Buku Ajar Penyakit Dalam. Jilid 1. Edisi 3. Jakarta: Balai Penerbit FKUI 